\title{
Is de term 'poldermodel' nog steeds politiek opportuun én wetenschappelijk bruikbaar?
}

\author{
Duco Bannink \& David Hollanders*
}

Poldermodel is de betekenaar waarmee het politiek-economische bestel zichzelf beschrijft. Naar aanleiding van de verschijning van de door Maarten Keune geredigeerde bundel Nog steeds een mirakel? De legitimiteit van het poldermodel in de eenentwintigste eeuw stelde de Sociaal-Economische Raad (SER) dan ook: 'twintig jaar geleden gold het Nederlandse poldermodel als lichtend voorbeeld'. De vraag of dat in 2016 onverkort het geval nog is, lag volgens de SER voor. SER-voorzitter Mariëtte Hamer stelde te dien aanzien: 'Typerend is de aanpassing van ons motto. Dat was altijd: denkwerk voor draagvlak. Vandaag is het "denkwerk voor draagvlak door dialoog".'

Allicht is het niet vergezocht de termen dialoog, draagvlak, poldermodel en lichtend voorbeeld allereerst te verbinden met Willem Schinkels (2008) bedenking bij een andere beleidsterm: samenleving. Schinkel stelt daarover:

“"Samenleving” is een term die iets doet, die betekent wat hij teweegbrengt. Dan wordt duidelijk dat "samenleving" een strategisch begrip is, waarvan we inderdaad niet moeten denken dat het verwijst naar een afgebakende sociale realiteit.'

Door vóór het woord model het woord polder te plaatsen is ooit een nieuw woord gevormd, waarmee de politiek-economische elite zichzelf beschrijft en waardoor ze zich associeert met alle daaraan verbonden adjectieven als redelijk, neutraal, compromisvaardig en nuchter. De zelfbeschrijving heeft trekken van een bezweringsritueel dat alle strijd - althans alle openlijke strijd - uit de politiek weren moet. Het is in elk geval deze sociale functie van de term 'poldermodel' waar Marianne Thieme (Partij voor de Dieren) onlangs haar pijlen op richtte. Zij stelde:

'Ik houd niet van gepolder en compromissen. De polder is visie- en zouteloos. Het beste resultaat ligt niet in het midden. Het Energieakkoord vind ik bijvoorbeeld een mislukking. De aarde is in crisis en dat vraagt om een radicale verandering. Ook bedrijven moeten de toets der duurzaamheid doorstaan. Dat betekent aanpassen of stoppen.'

$\mathrm{Nu}$, is de term 'poldermodel' een al dan niet strategisch gehanteerde sociale constructie? Of verwijst hij wel degelijk naar een sociale realiteit? Uiteraard moet het antwoord zijn: beide. De term is zowel betekenaar als betekende. Dat maakt het poldermodel zowel een interessant onderzoeksobject als een potentieel bruikbaar

* Dr. Duco Bannink is redactielid van Beleid en Maatschappij. Dr. David Hollanders is redactielid van Beleid en Maatschappij. 
analysemiddel. De bundel Nog steeds een mirakel? sluit aan bij de laatste benadering en vat 'poldermodel' op als een wetenschappelijke term waarmee de politieke economie van Nederland begrepen kan worden. De term 'polder' komt dan ook voor in de titel van vijf (inclusief de inleiding) van de negen bijdragen. In het voorwoord en de inleiding van Keune komt het woord 87 keer voor. De eerste zin van de inleiding kan daarbij als definitie worden opgevat:

'In het Nederlandse poldermodel onderhandelen verenigingen van werkgevers en werknemers en de overheid over sociaaleconomisch beleid en arbeidsvoorwaarden met als doel compromissen te bereiken over de inhoud van dit beleid en het onderling te coördineren.'

De tweede zin van de inleiding maakt vervolgens duidelijk dat de bundel een reflectieve actualisering is van Visser en Hemerijck (1997):

'Het boek (...) analyseerde de rol van onderhandelingen, coördinatie en consensus in Nederland en stelde vast dat dit cruciale factoren zijn geweest in het aanpakken van de lage groei en hoge werkloosheid van begin jaren 80, en in de goede performance van de Nederlandse economie en arbeidsmarkt in de jaren 90 .'

Hoewel de nadruk bij Visser en Hemerijck ligt op de jaren tachtig en negentig, maakt het werk van Hans Daalder plausibel dat 'poldermodel' een relatief nieuwe term is voor een ouder verschijnsel. Daalder beschreef in de bundels Van oude en nieuwe regenten (1990) en Politiek en historie (2011) het negentiende- en twintigste-eeuwse Nederland als een land met een vloeiende overgang tussen politiek en staat: 'Long tenure has made certain parties almost indistinguishable from the formal state apparatus' en een naar binnen gekeerde elite: '[Nederland] wel een eigen establishment [heeft], maar dat dit zich niet als zodanig laat zien, of althans wil laten zien, en dat het zich niet met overtuiging in de publieke politieke strijd begeeft, maar zich bewust-conformerend in afgeslotenheid isoleert.'

Kortom, Daalder schetste enige karakteristieken van het poldermodel - de vloeiende overgang tussen politiek en staat, de afwezigheid van openlijke politieke strijd -, die door gebruik van de term 'polder' weer benadrukt en gereproduceerd worden. Om Schinkel te parafraseren, 'poldermodel' betekent altijd ook weer dat wat gebruik van de term in het leven roept.

Alleen al vanwege het strategische gebruik van de academisch beschrijvende term 'poldermodel' is het laatste woord erover nooit geschreven. Dat is met deze Reflectie \& debat al letterlijk zo. Hier reflecteren Alexandre Afonso en Christoffer Green-Pedersen op de bundel. Afonso stelt dat: 'Dutch neo-corporatism (...) still displays a remarkable degree of stability compared with other European countries', maar dat 'While it is unlikely to disappear, it may however be deprived of much of its regulatory capacity in a context of financialisation.' 
Financialisering beperkt dus de effectiviteit en reikwijdte van het poldermodel. De rechts-populistische PVV contesteert, volgens Afonso, het model als zodanig:

'Trade unions typically represented the socio-economic clienteles that the PVV is now mostly claiming, namely older, low-and-middle skilled working class workers. Weakening their influence can also be part of a strategy to become the only voice of this constituency.'

Christoffer Green-Pedersen komt uit Denemarken. Hij promoveerde in de jaren nul op het poldermodel, althans op een proefschrift met de titel The Politics of Justification, waarin de gang van zaken rond de grote herzieningen van de jaren tachtig en negentig in Nederland werd vergeleken met die in Denemarken. Hij stelt dat corporatistische systemen van afstemming niet zozeer op hun inputlegitimiteit zouden moeten worden beoordeeld (die is sowieso problematisch), maar op hun output. De vragen die het boek van Keune stelt over de inputlegitimiteit van het systeem, leiden daar misschien wat van af. Als het corporatistische systeem niet levert, dan is niet de inputlegitimiteit van het corporatisme, maar zijn bestaansrecht de kwestie waar het om draait. En daarmee verschuift de vraag, zo stelt Green-Pedersen: een effectieve polder vereist een sterke regering, maar is die regering eigenlijk wel sterk geweest in de afgelopen jaren? Dat betekent, denken we, dat Green-Pedersen graag had gezien dat het Nederlandse corporatisme in een wat bredere context was geplaatst, op twee niveaus: Wat kwam er eigenlijk uit? En in welke omgeving moest het functioneren? Tja, misschien is dat motto van Mariëtte Hamer waarmee we openden dus gevaarlijk: 'denkwerk voor draagvlak', waarbij dat denkwerk al (nu) dan niet (vroeger) gebeurt via dialoog en in ieder geval 'voorafgaat aan' of wordt gedaan 'ten behoeve van' het draagvlak, maar in beide gevallen een zeker primaat heeft boven die context.

\section{Literatuur}

Daalder, H. (1990). Van oude en nieuwe regenten. Politiek in Nederland. Amsterdam: Bert Bakker.

Daalder, H. (2011). Politiek en historie. Opstellen over Nederlandse politiek en vergelijkende politieke wetenschap (red. J.Th.J. van den Berg en Bart Tromp). Amsterdam: Bert Bakker.

Schinkel, W. (2008). De Gedroomde Samenleving. Klement.

Thieme, M. (2017). Interview. Forum. www.vno-ncw.nl/forum/marianne-thieme-groei-niet -de-oplossing-voor-alles, geraadpleegd op 9 januari 2017.

Visser, J., \& Hemerijck, A. (1997). Een Nederlands Mirakel. Amsterdam: Amsterdam University Press. 